\title{
Janusz Mariański, Godność ludzka - wartość ocalona? Studium socjopedagogiczne, Płock: Plocki Instytut Wydawniczy, 2017, s. 204.
}

DOI: http://dx.doi.org/10.12775/PCh.2017.036

W samym centrum problemów moralnych, bardzo ważnych dla kulturowej i moralnej przyszłości Europy, a nawet świata, znajduje się problem godności ludzkiej. Fundament dla godności osoby ludzkiej znajduje się w Biblii, a uczynił go Bóg, stwarzając człowieka ,na swój obraz, na obraz Boży go stworzył: stworzył mężczyznę i niewiastę" (Rdz 1, 27).

Ks. prof. dr hab. Janusz Mariański, emerytowany profesor socjologii religii i socjologii moralności w Katolickim Uniwersytecie Lubelskim Jana Pawła II, problem godności ludzkiej w aspekcie socjopedagogicznym przedstawił w jednej z najnowszych swoich książek pt. Godność ludzka - wartość ocalona (Płock 2017), dodając tę pozycję do pięćdziesięciu już wcześniej wydanych. Książka ta zawiera trzy spójne ze sobą rozdziały, wstęp i zakończenie, bibliografię, kartę tytułową, wykaz skrótów, notę bibliograficzną oraz streszczenie w języku angielskim.

We wstępie Autor, dokonując rzeczowego wprowadzenia do podjętego problemu godności człowieka, przygotował czytelnika do odbioru tej pozycji. Nawiązał najpierw do obecności zagadnienia godności człowieka w filozofii i kulturze greckiej, wspomniał o jego obecności w filozofii i teologii średniowiecza, w czasach nowożytnych i skoncentrował się na współczesności. Pisząc o wadze problemu godności ludzkiej, thumaczy sens tego pojęcia, wspomina o powszechnym prawie do godności i obowiązku jej poszanowania, wskazuje na miejsca i publikacje naukowe, w których przywoływana i prezentowana jest godność jako wartość. Z kolei ukazuje godność ludzką jako wartość fundamentalną, istniejące niebezpieczeństwo w różnym okre- 
ślaniu godności w życiu codziennym (np. aborcja, narkotyki), a także dawanie wymijających odpowiedzi na pytanie, czym jest godność człowieka przez kulturę współczesną (stąd relatywizm etyczny) oraz ataki na godność ludzką jako wartość. Stawia w końcu także cały szereg pytań - z socjologicznego punktu widzenia - dotyczących godności ludzkiej jako wartości fundamentalnej, osobowościowej i osobistej. Podkreśla wartość wychowania do godności, konieczność wychowania progodnościowego jako integralnej części wychowania moralnego, a także - potrzebę zajmowania ważnego miejsca w ideale „dobrego życia” jednostki i społeczeństwa oraz w wychowaniu moralnym przez wartości godnościowe.

Poszczególne rozdziały prezentowanej książki, które poruszają trzy zagadnienia z zakresu: godności osobowej, osobowościowej i osobistej (I), godności ludzkiej jako wartości społecznej i sytuacji, które jej zagrażają (II), i wychowania do wartości godnościowych (III), tworzą logiczny układ, w którym pierwszy rozdział swoją treścią domaga się drugiego, a obydwa razem (I i II) mają swoje dopełnienie w trzecim, tworząc ten sam obszar tematyczny.

Obszar obejmujący zagadnienie: „Godność osobowa (ludzka zwana też człowieczeństwem), osobowościowa i osobista (własna, jednostkowa; można ją utracić)" Janusz Mariański rozpoczął zapełniać od podkreślenia wagi „godności ludzkiej będącej wartością fundamentalną”. Godność ta bowiem jest podstawą normatywną praw człowieka, porządkującą i najogólniejszą wartością i normą ładu społecznego. Autor - podając różne definicje godności osobowej - poucza o jej znaczeniu w życiu człowieka, a mianowicie, że jest jego pozytywną wartością, że wynosi człowieka ponad rzeczy, że przysługuje każdemu człowiekowi bez wyjątku, co sprawia, że wszyscy ludzie są sobie równi, że nie można człowieka jej pozbawić ani on nie może się jej zrzec, że jest nieusuwalna i niestopniowalna, że jest zasługująca na szacunek własny i innych ludzi. Z tak pojętej godności wyrastają inne wartości: jedność, wspólnotowość, miłość, sprawiedliwość i wolność. Autor poucza również o - mających ważne znaczenie teoretyczne i praktyczne - różnych typach godności: np. A: trzy jej pojęcia: 1) godność osobowa, 2) osobowościowa, 3) osobista; B: cztery podstawowe rodzaje: 1) godność istotowa, 2) moralna, 3) społeczna, 4) godność twórczości; C: cztery koncepcje: 1) godność jako wartość stopniowalna, 2) godność w ujęciu teologicznym, 3) godność wynikająca z umiejętności kierowania się rozumem i dokonywania racjonalnych wyborów, 4) godność chroniąca prawa człowieka; D: godność jako specyficzna potencjalność; E: godność wrodzona (dana) i nabyta (zadana); F: godność absolutna i relatywna; G: godność w sensie filozoficznym i teologicznym (godność bezwarunkowa) i godność w sensie 
empirycznym (warunkowa). Wielorakie ujęcia godności osobowej (wrodzonej) prowadzą Autora do stwierdzenia o jej niezwykłej wartości dla człowieka, a mianowicie: że jest on zawsze wartością samą w sobie i nigdy nie może być potraktowany jako przedmiot, narzędzie czy rzecz; że godność ta jest niezniszczalna nawet w przypadku grzechu czy utracenia poczucia godności ludzkiej; jest ona podstawą równości; nie można mieć jej ani więcej ani mniej, ale można w niej wzrastać (postulat). W ujęciu chrześcijańskim godność osoby ludzkiej jest niezniszczalnym obrazem Boga Stwórcy, identycznym w każdym człowieku. Biorąc pod uwagę godność osobowościową czy osobistą, jest ona człowiekowi zadana i należy do niej dorastać. Ponadto ma ona charakter moralny.

Godność ludzka, według społecznego nauczania Kościoła katolickiego, to drugi paragraf pierwszego rozdziału na temat "Godność osobowa, osobowościowa i osobista". Autor oparł się na normatywnej koncepcji osoby ludzkiej, ponieważ ma ona swoje uzasadnienie naturalne (filozoficzne) i nadprzyrodzone (teologiczne). Osoba ludzka, ze względu na swoją godność absolutną, która stanowi wartość ontyczną, nie może być traktowana instrumentalnie. Natomiast od strony transcendentnej jej godności, osoba stanowi wartość najwyższą przez swoje podobieństwo do Boga (imago Dei) oraz jako istota odkupiona przez Chrystusa. Ta afirmacja godności osoby dotyczy również wszystkich ludzi (każdy z nich jest osobą równoprawną). Godność osoby w znaczeniu teologicznym ubogaca i potwierdza jej godność w znaczeniu naturalnym. Katolicka nauka społeczna podaje nadprzyrodzoną godność osoby - co podkreśla Mariański - jako podstawę normatywną przysługujących osobie uprawnień. Prawo naturalne wyraża godność osoby oraz jest podstawą jej fundamentalnych praw i obowiązków. Godność człowieka zatem jest podstawą porządku, jest najogólniejszą wartością i normą ładu społecznego. Teologiczna koncepcja godności osoby ludzkiej współbrzmi z filozoficznymi ujęciami godności, które godność charakteryzują jako wartość bezwarunkową, przysługującą każdej osobie i będącą podstawą praw człowieka. Szczególne znaczenie godności osoby ludzkiej, jako fundamentalnej wartości społeczno-moralnej, Autor dostrzega dla socjologii moralności o orientacji personalnej. Ta dziedzina wiedzy jest mu szczególnie bliska jako jedna z jego specjalności. Autor, analizując społeczne nauczanie Kościoła, prezentuje zasadnicze prawdy w nim zawarte, jak np. że: osoba ludzka, taka jaką ją stworzył Bóg, jest fundamentem i celem życia społecznego; istnieje więź wiary w Boga z uznaniem godności ludzkiej; nikomu nie wolno znieważać bezkarnie godności ludzkiej, do której sam Bóg z wielkim szacunkiem się odnosi; w godności człowieka mają swój fundament obiek- 
tywne i nienaruszalne prawa człowieka; godność ludzka jest definiowana w wymiarze nadprzyrodzonym (teologicznym) i przyrodzonym (filozoficznym); katolicka nauka społeczna obok godności osobowej wyróżnia jeszcze godność osobowościową - nabywaną przez wychowanie i pracę nad sobą (osobista - poczucie własnej wartości, społeczna, kulturowa); rozwój integralny człowieka jest imperatywem moralnym, gdyż człowiek jest zobowiązany stawać się człowiekiem. Janusz Mariański słusznie opowiada się za nakazem urzeczywistniania, a nie tylko głoszenia i propagowania, nauczania społecznego Kościoła o godności.

W uwagach końcowych (3), Autor podkreślił, iż w swoich rozważaniach dotyczących społecznego nauczania Kościoła katolickiego będzie się przeważnie odwoływał do normatywnego (wartościującego) ujęcia godności, a nie do nienormatywnego (opisowego, niewartościującego). I przypomniał klika zasadniczych prawd o godności osoby ludzkiej, z której wynikają wartości trwałe, obiektywne i uniwersalne oraz prawa człowieka.

Kontynuując problem godności ludzkiej w drugim rozdziale, Autor przedstawił ją jako wartość społeczną oraz wskazał na sytuacje jej zagrażające (II). Uwzględnił zatem dwie podstawowe kwestie: psychologiczne i społeczne ujęcia godności ludzkiej (perspektywa psychologiczna i socjologiczna), czyli opisowe ujęcie tej godności określanej jako godność kulturowa, osobowościowa, osobista i immanentna (1. kwestia) oraz sytuacje społeczne, które naruszają godność osoby ludzkiej (2. kwestia).

Podejmując pierwszą kwestię, Autor wychodzi od przypomnienia, że godność osobowościowa i osobista nie przysługują automatycznie każdemu człowiekowi, ale kształtują się one powoli i są efektem podejmowanego trudu rozwoju na kolejnych etapach życia człowieka, podobnie jak inne właściwości człowieka. Nie są one również kategorią normatywną, lecz opisową, są przedmiotem badań empirycznych: psychologicznych i socjologicznych. Janusz Mariański zapoznaje $\mathrm{z}$ odpowiednimi badaniami w naukach społecznych (psychologia, pedagogika, socjologia), przytacza definicje godności ludzkiej z psychologicznego punktu widzenia oraz charakterystyczne fragmenty z opracowań różnych autorów. Wynika z nich, że: 1) godność $w$ znaczeniu psychologicznym $i$ społecznym jest właściwością wtórną, mającą charakter warunkowy, jest zmienna i utracana. Można ją udoskonalać, rozwijać i dopełniać. Ponadto obok godności pojmowanej jako cnota pojawia się wzrost znaczenia godności jako przywileju, jako prawa do korzystania z określonych dóbr. 2) Godność w ujęciu psychologicznym stanowi szczególną wartość człowieka jako osoby pozostającej w relacjach interpersonalnych, uzasadniających i usensowniających życie osobiste, a także pozy- 
tywnie wartościuje relacje do własnej osoby i grupy społecznej, z którą jednostka się identyfikuje. Godność człowieka należy definiować jako wartość samą w sobie, będącą w opozycji wobec jej wartości dla innych. W poczuciu wolności jest podstawa godności, w niej godność jest ugruntowana (Viktor E. Frankl). Odróżnia się godność ludzką, będącą pojęciem normatywnym (związana jest z prawami człowieka), i godność osobistą (stanowi cechę charakteru), związaną z pojęciem opisowym. Od godności osobistej należy odróżnić poczucie godności. Przeciwieństwem postawy godnościowej (godnej) jest postawa niegodnościowa, niegodna, zwana niekiedy pragmatyczną (Józef Kozielecki). Ocena moralna postawy godnościowej musi wiązać się z systemem wartości, jakiemu służy dana jednostka lub grupa społeczna, jakiego broni i jakiemu podporządkowuje swoje postawy i zachowania. 3) Socjologowie zwracają uwagę na społeczne aspekty godności ludzkiej, analizują różne postaci poniżania człowieka i nierespektowania jego praw do godnego życia. Godność jako fakt społeczny łączy się z dobrym imieniem, dobrą sławą, szacunkiem, zdolnością poświęcania się, umiejętnością obrony wyznawanych wartości. Składają się na nią cztery elementy: poczucie własnej wartości, nabywanie cnoty, zdolność obrony uznawanych wartości i z tej racji należny człowiekowi szacunek. Z punktu widzenia socjologicznego godność to pewna cecha lub stan, który: a) bywa uzyskany przez wydarzenia naturalne (np. urodzenie) lub kulturowe (nadane z zewnątrz); b) można czasem go utracić; c) utraciwszy można go odzyskać; d) związana jest z przynależnością do pewnego zbioru; e) pociąga za sobą pewne zobowiązania; f) pociąga za sobą pewne roszczenia (Andrzej Grzegorczyk). Godność nie jest wrodzoną czy naturalną jakością ludzkiej egzystencji, lecz wynikiem udanej samoświadomości i indywidualności (tę zdobywa się jako partner w interakcjach społecznych). Socjolog nie szuka transcendentnych czy transcendentalnych uzasadnień moralności ani absolutnych powinności etycznych, lecz stara się uchwycić społeczne funkcje moralności (Niklas Luhmann). Proces upowszechnienia się praw człowieka wynika ze swoistej sakralizacji osoby ludzkiej, która jest postrzegana jako pełna niezbywalnej godności, a uniwersalna godność ludzka jest podstawą praw człowieka. Nie warto tracić czasu na jałowe spory, czy coraz większa powszechność pojęcia godności ludzkiej jest powiązana z religią, czy też niepowiązana. Ważne jest to, że pojęcie godności jest bliskie zarówno chrześcijanom, jak i niewierzącym (Hans Joas). Godność ma ten, kto umie bronić pewnych uznanych przez siebie wartości, z których obroną jest związane jego poczucie własnej wartości i kto oczekuje $\mathrm{z}$ tego tytułu szacunku ze strony innych. Brak godności $\mathrm{z}$ kolei ujawnia ten, kto rezygnując $\mathrm{z}$ takiej wartości sam siebie poniża lub 
daje się poniżać dla osiągnięcia jakichś osobistych korzyści. Socjolog nie zajmuje się godnością w sensie ontologicznym, lecz tą godnością, która nie przysługuje automatycznie człowiekowi jako takiemu (Maria Ossowska). Daje się wyróżnić cztery typy orientacji moralnej: tabuistyczna, wzajemnościowa, prospołeczna i godnościowa. W tej ostatniej wartością nadrzędną jest nie tyle dobro drugiego człowieka, ile swoiste dobro osoby, pewna wartość osobista „wyższego rzędu”. Godność jest związana z ideą szacunku, jaki jednostka ma prawo odczuwać dla siebie jako (autonomicznej) wartości, a także z poczuciem prawa do obrony tej wartości oraz domagania się respektu dla niej ze strony innych (Krzysztof Kiciński). Temu, co jest określane jako godność osoby ludzkiej, jako godność osobowościowa i osobista, bliskie jest okazywanie szacunku i szacunek. Chcąc jednak, aby szacunek był w społeczeństwie wartością ocaloną, potrzebne jest kształtowanie w ramach edukacji i wychowania kompetencji etycznych. Fundamentalną sprawą dla odrodzenia tkanki społecznej jest kształtowanie dwóch kompetencji moralnych: a) aby obdarzano szacunkiem tych, których trzeba, niezbędna jest zdolność odróżniania dobra od zła, prawdy od udawania, autentyczności od pozorów; b) aby ludzie szanowali się sami, czyli cenili zdobyty szacunek i nie naruszali go do niegodziwych celów, potrzebna jest etyczna odpowiedzialność (Piotr Sztompka). Osobista godność i honor należały do typowych wartości kultury polskiej. Ale po roku 1989 wytworzyła się sytuacja niesprzyjająca kształtowaniu i wzmacnianiu postawy godnościowej i postawy honoru. Ważne stanowiska państwowe, społeczne i gospodarcze zajęli ludzie o niejednoznacznych postawach w kwestiach światopoglądowych, religijnych, społecznych i gospodarczych. Nie postawa godnościowa w połączeniu z postawą służby dobru wspólnemu, lecz postawa gonitwy za korzyścią osobistą, rodzinną i partyjną zdominowała decyzje w sprawach publicznych. Godność i honor, niegdyś tak wysoko cenione w publicznym życiu społecznym, mocno osłabły (Leon Dyczewski). Przemianom ustrojowym w Polsce towarzyszyło zjawisko kryzysu normatywności, a nawet jej destrukcja. Przejawem tego był rozpad norm społecznych (kulturowych i etycznych), jako ogólnych reguł postępowania i powszechnej mocy obowiązywania. Miejsce norm zajmuje partykularyzm, doraźność, przypadkowość. Prawdę trudno odróżnić od kłamstwa, cnotę od występku, szlachetność od niegodziwości (Andrzej Kojder).

W wymienionych koncepcjach godności ludzkiej akcentuje się różne aspekty godności społecznej: honor, prestiż, uznanie, podmiotowość, szacunek dla jednostki i dla innych ludzi, sakralizacja osoby. Natomiast wspólne dla wszystkich jest ujmowanie godności społecznej jako rzeczywistości 
zmiennej, nabytej, zależnej od struktury lub kultury danego społeczeństwa. W analizach psychologicznych i socjologicznych ujmowana jest godność jako cecha charakteru lub jako poczucie godnościowe. W rozważaniach z zakresu nauk empirycznych godność ludzką traktuje się jako wielkość stopniowalną, charakteryzującą w zróżnicowany sposób poszczególne jednostki, grupy społeczne i całe społeczeństwo. Socjolog o orientacji empirycznej jest szczególnie uczulony na uwarunkowania społeczne godności osoby ludzkiej w społeczeństwach współczesnych. Z socjologicznego pun$\mathrm{ku}$ widzenia wartości godnościowe mają przede wszystkim walory społeczne. Mówiąc o godności jako wartości społecznej, mniej są podkreślane momenty odczuć psychicznych w zakresie wierności sobie, natomiast bardziej zwraca się uwagę na warunki społeczne, w których postawy i zachowania godnościowe są kształtowane, rozwijane lub naruszane. W nauczaniu społecznym Kościoła katolickiego ocenia się z punktu widzenia etycznego wszelkie przejawy degradacji człowieka i różne systemy niesprawiedliwości w wymiarach społecznych. Najwyższą wartością porządku społecznego i moralnego jest człowiek ujmowany jako osoba w swej godności przyrodzonej i nadprzyrodzonej.

Po wyczerpującym przedstawieniu zagadnień pierwszego rozdziału Janusz Mariański zaprezentował sytuacje społeczne naruszające godność ludzką (rozdz. 2). Rozpoczął od spostrzeżeń socjologów, którzy wskazują różne dziedziny życia, w których ma miejsce dezaprobata godności ludzkiej, np. ograniczanie rozwoju osoby, pozbawienie jej uprawnień, obniżanie jej mocy, instrumentalizacja człowieka, uważanego i traktowanego jak rzecz, przez: schlebianie, narzucanie się komuś, okazywanie ślepego posłuszeństwa, oportunizm (działanie wbrew swoim przekonaniom, dla awansu społecznego, dla „świętego spokoju”), nieumiejętność opanowania jakiegoś nałogu (człowiek, który woli żebrać niż pracować), branie udziału w publicznych konkursach piękności, sprawy związane z nieograniczoną erotyką, upokorzenie przez danie się oszukać, traktowanie człowieka jako towar (np. człowiek jako anonimowa siła robocza, zarówno dobrobyt, jak i dostatek może sprzyjać albo szkodzić godności). Brak swojej godności objawia ten, kto rezygnuje z własnych wartości lub daje się poniżać dla jakichkolwiek korzyści. Bardzo łatwo traci swoją godność ten, kto nie chce być odpowiedzialny za swoje wypowiedzi czy działania. Godność społeczeństwa i godność jednostek ściśle łączą się ze sobą, gdyż tylko w godnym społeczeństwie realizuje się godność jednostek.

Autor wymienia różne dziedziny życia, w których godność jest naruszana, wskazane również w nauczaniu społecznym Kościoła, takie jak: nieludz- 
kie warunki życia, arbitralne aresztowania, deportacje, niewolnictwo, prostytucja, handel kobietami i młodzieżą, nieludzkie warunki pracy (KDK 27); przemoc i terroryzm, różne formy dyskryminacji rasowej, kulturalnej, religijnej, nagromadzenie broni, wyścig zbrojeń (RP 2), fetyszyzm pieniądza, plaga handlu ludźmi, wyzysk, traktowanie ludzi jak przedmioty, brak pożywienia, pracy, kultura śmierci, brak szacunku dla wszelkiego życia, marnotrawienie stworzenia, gdy konsumujemy tylko dla siebie, wolność bez granic, nierówność społeczna, ekonomia wykluczenia, bałwochwalstwo pieniądza, nierówność społeczna rodząca przemoc, bezrobocie wśród młodzieży, brak praw pracowniczych, traktowanie istoty ludzkiej jako dobro konsumpcyjne, prywatyzacja zasobów wody, wykluczenie społeczne, szalejąca konsumpcja, degradacja środowiska przyrodniczego, wypaczony antropocentryzm, relatywizm praktyczny, niepotrzebne zadawanie cierpień zwierzętom oraz ich zabijanie, brak własnego mieszkania, wykorzystywanie fizyczne, gospodarcze, psychiczne, seksualne każdego człowieka, handel narządami, przymusowa ciężka praca, dzieci-żołnierze, ofiary przemocy, uważanie starszych za „odpady”, ubóstwo rodzin, alkoholizm, narkomania, kupczenie godnością, brak miłosierdzia dla drugich przy korzystaniu z Bożego miłosierdzia, wszelkie działania moralnie naganne (papież Franciszek). Janusz Mariański, przedstawiając naruszenia godności ludzkiej, niezwykle tę kwestię zaktualizował. Zaprezentował bowiem sytuacje społeczne dotyczące współczesnego człowieka, dzisiejsze, rozgrywające się wprost na naszych oczach (świadczy o tym chociażby powoływanie się głównie na papieża Franciszka), które codziennie proszą, aby się nimi zająć, ponieważ świat przez swoją opieszałość traci codziennie na swojej godności.

W uwagach końcowych (3) Autor krótko zebrał treść opracowanej kwestii, zaproponował materiał dla przyszłych badań socjologicznych, a także dla empirycznej socjologii moralności, wykorzystanie społecznej nauki Kościoła katolickiego jako bardzo dobrej podstawy oraz wskazał na wartość wychowania progodnościowego.

Janusz Mariański, po należytym przygotowaniu czytelnika w pierwszym i drugim rozdziale swojej pracy, wprowadza go następnie w praktyczną, wprost życiową wartość swojego opracowania, przedstawiając: „Wychowanie do wartości godnościowych" (III). Rozpoczął zatem zgodnie z logiką od skoncentrowania się na przybliżeniu „pojęcia wychowania moralnego” (1). Przedstawił najpierw wychowanie w sensie najszerszym, cel działania wychowawczego, wychowanie jako środek do celu, określenie celu oraz rodzaje wychowania, wśród których znajduje się również wychowanie moralne. Wspomniał o funkcji socjologicznej wychowania, o wychowaniu personali- 
stycznym (wychowanie chrześcijańskie: Józef Majka). Z kolei zaakcentował cel wychowania moralnego, działania w procesie tego wychowania (5 działań); przybliżył wychowanie moralne z socjologicznego punktu widzenia; wychowanie moralne chrześcijańskie (moralność katolicka); realizację wychowania na dwóch płaszczyznach: a) kształtowanie postaw, b) płaszczyzna struktur. W końcu rozpracował kwestię godności osoby ludzkiej jako fundamentu wychowania. Wychowanie moralne bowiem rozumiane jest jako wychowanie do człowieczeństwa (godności). We współczesnym wychowaniu istnieje konieczność budzenia poczucia godności osobowej wychowanka i jej poszanowania. Stąd konieczność akcentowania w wychowaniu moralnym nie tylko takich wartości jak: prawda, wolność, sprawiedliwość, ale również godność ludzka jako wartość podstawowa, jako horyzont i cel aktywności wychowawczej. Podano bardzo wartościowy opis czterech etapów wychowania do godności, która jest człowiekowi dana i zadana, a także - odnoszące się do relacji między wychowawcą i wychowankiem, opartej na godności osoby - cztery działania ochronne i cztery promujące godność. Wychowanie progodnościowe (personalistyczne) prowadzi do formowania integralnie rozumianego człowieka, rozwijania w nim tego, co ludzkie, by pełniej stawał się człowiekiem, by umiał być nie tylko innym, ale i dla innych, do utrwalania więzi z prawdą i dobrem.

Po gruntownym przedstawieniu materiału dotyczącego pojęcia wychowania moralnego, bardzo ściśle związanego $\mathrm{z}$ wychowankiem progodnościowym, a właściwie identyfikującego się z nim, Janusz Mariański zaprezentował podstawową instancję wychowawczą - „Rodzinę jako środowisko kształtowania postaw godnościowych" (2). W świetle wypowiedzi różnych autorów, także papieży, Autor ukazał, czym jest rodzina szczególnie dla dziecka oraz jaką ma rolę do spełnienia. Wychowanie dziecka w rodzinie do poczucia godności osoby jest procesem sprzyjającym budowaniu jego prawidłowej osobowości. Oceny wartościujące typu „dobry”, „zły” dziecko poznaje już w pierwszym okresie swojego życia. Podobnie w rodzinie kształtuje się właściwe rozumienie i przeżywanie wolności uspołecznionej i odpowiedzialnej. W rodzinie kształtuje się nie tylko poczucie godności osobistej ale także dokonują się procesy uspołecznienia. Rodzina jest najważniejszym środowiskiem odniesienia normatywnego. Wychowanie moralne dziecka w rodzinie, która jest pierwszą szkołą cnót społecznych i moralnych, jest rezultatem wielorakich wpływów, ale istotne znaczenie ma całościowa atmosfera domu rodzinnego. Bardzo ważnym warunkiem oddziaływań wychowawczych są rozmowy rodziców z dziećmi. Tę wypowiedź Autor poparł badaniami CBOS z 2013 roku. Podał również wyniki badań CBOS z roku 
2010 na temat dopuszczalności bicia dzieci. Zebrany materiał pozwolił Autorowi na stwierdzenie, że rodzina polska utrzymuje - mimo wielu zmian społeczno-kulturowych - wciąż ważne miejsce w procesie społecznego i moralnego wychowania dzieci i młodzieży. Budzi się jednak obawa, że w przyszłości należy liczyć się z niebezpieczeństwem zmniejszenia się funkcji wychowawczych rodziny.

W „uwagach końcowych” (3) Autor umieścił wiele ważnych podsumowujących stwierdzeń, a pierwszym z nich jest przekonanie, że każda istota ludzka ma równą godność, wynika stąd, że społeczeństwo musi dostosować swoje struktury do tego podstawowego założenia. Niepokój powinno budzić stwierdzenie wynikające z badań socjologicznych, że ludzie współcześni odnoszą się ze sceptycyzmem do wszelkich wartości. Na temat pluralizmu kulturowego czy pluralizmu moralnego stwierdził, że ważne jest potwierdzenie, że ani jeden, ani drugi nie może oznaczać rezygnacji z dążenia do prawdy i do respektowania wartości ogólnoludzkich. Pozostałe podsumowania dotyczą: realizacji przez człowieka siebie poprzez czyny moralnie dobre, efektu wychowania moralnego z punktu widzenia socjologicznego, różnych sposobów oddziaływań rodziców, konieczności podstawowej świadomości norm moralnych dla życia ludzkiego. Ponadto Janusz Mariański wyraził życzenie, by nauki społeczne podejmowały w większym zakresie problematykę godności ludzkiej.

W zakończeniu Janusz Mariański zamieścił - zgodnie z wymogami stawianymi tego rodzaju opracowaniom - efekty swoich badań (wnioski i postulaty), w których wykazał, że godność ludzka jako wartość może być wartością ocaloną. Należy jednak spełnić określone wymagania, takie jak: osobę ludzką trzeba umieścić w centrum wszystkich projektów rozwoju ludzkiego; powszechne przekonanie, że odwoływanie się do wartości moralnych, a wśród nich do wartości, jaką jest godność ludzka, ma swoją legitymizację w naturze ludzkiej; godność ludzką w sensie empirycznym (godność warunkowa), można utracić, ale można ją również pogłębić, co stanowi imperatyw moralny; każdy człowiek ma prawo oczekiwać od społeczeństwa i państwa uszanowania i respektowania jego godności ludzkiej; godność osoby ludzkiej można lepiej zrozumieć dzięki analizie przypadków jej naruszania; trwałe i niepodważalne wartości stanowią konieczny warunek rozwoju osoby ludzkiej oraz fundament prawdziwego postępu i rozwoju; kondycja moralna społeczeństw zależy ostatecznie od samych ludzi wywołujących kierunkowe zmiany i kształtujących procesy społeczne; socjologia ma obowiązek pomagać ludziom w rozpoznawaniu problemów moralnych oraz wskazywać, co jest potrzebne dla ich rozwiązywania i w jakim kierunku 
powinny iść zmiany w społeczeństwie; socjolog uznaje, że społeczeństwo powinno mieć moralność jako swój konstytutywny wymiar i że są wartości moralne, z których nie można zrezygnować w społeczeństwie; polityka nie może być alternatywą dla wartości moralnych, a zwłaszcza dla godności osoby ludzkiej, która jest wartością samą w sobie, wynikającą z istoty człowieczeństwa; Kościół katolicki chce współdziałać z tymi, którzy działają na rzecz sprawiedliwości i solidarności, którzy bronią człowieka i wzywają do poszanowania ludzkiej godności; Kościół katolicki w Polsce, służący człowiekowi w każdej potrzebie, musi mieć świadomość, że ludzie właściwie oczekują od niego pomocy na płaszczyźnie moralnej.

Janusz Mariański, w świetle recenzowanej pracy pt. Godność ludzkawartość ocalona. Studium socjopedagogiczne, okazał się doskonałym znawcą podjętego problemu, który obejmuje zakres godności osobowej, osobowościowej i osobistej. Godność ludzką ukazał jako wartość społeczną, a także wskazał na sytuacje społeczne, które naruszają tę godność. Prawdziwym uwieńczeniem podjętego problemu jest zagadnienie wychowania do wartości godnościowych. Autor w swoim opracowaniu ukazał problem wieloaspektowo, uwzględniając spojrzenie nie tylko socjologiczne, ale również psychologiczne, pedagogiczne i chrześcijańskie. Dużym ubogaceniem recenzowanej książki jest częste odnoszenie się do społecznej nauki Kościoła katolickiego, pozwalające czytelnikowi poszerzać swoje horyzonty myślowe. Ponieważ treść tej pozycji socjopsychologicznej dotyczy pierwszoplanowo godności osoby ludzkiej oraz wychowania do wartości godnościowych, zaadresowana jest ona do szerokiego grona odbiorów, w różnym wieku i różnych wyznań, a nawet niewyznających żadnej religii, ponieważ poczucie godności ludzkiej i troska o jej respektowanie jest problemem ogólnoludzkim, znosi wszelkie podziały religijne, społeczne i narodowe. Szczególnie jednak z tą niezwykle cenną pozycją powinni zapoznać się wychowawcy, nauczyciele, rodzice oraz ci wszyscy, którym dobre wychowanie młodego pokolenia Polaków leży głęboko na sercu.

Helena Stotwińska*

* Prof. dr hab. Helena Słotwińska jest kierownikiem Katedry Katechetyki Integralnej w Instytucie Teologii Pastoralnej i Katechetyki Katolickiego Uniwersytetu Lubelskiego Jana Pawła II. Adres: Instytut Teologii Pastoralnej i Katechetyki KUL, al. Racławickie 14, 20-950 Lublin; e-mail: helena.slotwinska@kul.pl. 